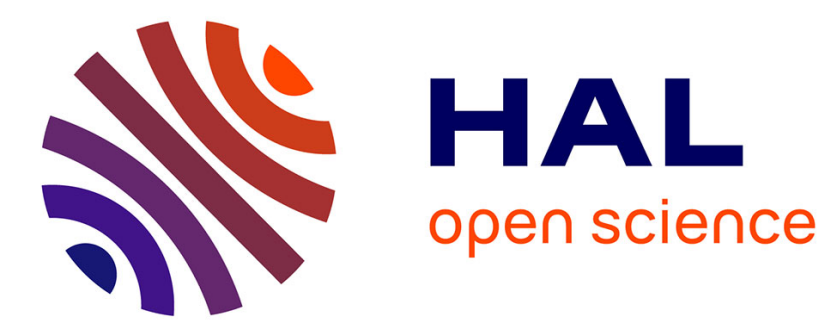

\title{
Rare primary extranodal lymphomas: diffuse large B-cell lymphomas of the genital tract
}

Péter Rajnics, Judit Demeter, Judit Csomor, László Krenács, László Pajor, Balázs Kollár, Zsuzsanna Kertész, Miklós Egyed

\section{- To cite this version:}

Péter Rajnics, Judit Demeter, Judit Csomor, László Krenács, László Pajor, et al.. Rare primary extranodal lymphomas: diffuse large B-cell lymphomas of the genital tract. Annals of Hematology, 2009, 88 (12), pp.1223-1228. 10.1007/s00277-009-0741-7 . hal-00535052

\section{HAL Id: hal-00535052 \\ https://hal.science/hal-00535052}

Submitted on 11 Nov 2010

HAL is a multi-disciplinary open access archive for the deposit and dissemination of scientific research documents, whether they are published or not. The documents may come from teaching and research institutions in France or abroad, or from public or private research centers.
L'archive ouverte pluridisciplinaire HAL, est destinée au dépôt et à la diffusion de documents scientifiques de niveau recherche, publiés ou non, émanant des établissements d'enseignement et de recherche français ou étrangers, des laboratoires publics ou privés. 


\title{
Rare primary extranodal lymphomas: diffuse large B-cell lymphomas of the genital tract
}

\author{
Péter Rajnics • Judit Demeter • Judit Csomor • \\ László Krenács • László Pajor • Balázs Kollár • \\ Zsuzsanna Kertész • Miklós Egyed
}

Received: 25 April 2008 /Accepted: 23 March 2009 /Published online: 8 April 2009

(C) Springer-Verlag 2009

\begin{abstract}
Primary non-Hodgkin's lymphoma (NHL) of the genital tract is a rare entity. Etiology and pathogenesis of these NHLs are unknown, although there might be a possible association between chronic inflammation and lymphomas. The most common histological subtype is the diffuse large B-cell lymphoma. We report two cases of uterine lymphoma and one case of prostate lymphoma in this paper. The symptoms and the differential diagnosis are also discussed. Because of the low incidence, there is no widely accepted consensus on its treatment. We demonstrate that the rituximab and CHOP (cyclophosphamide, doxorubicin, vincristine, and prednisone; R-CHOP) chemoimmunotherapy is a good and tolerable treatment option in
\end{abstract}

P. Rajnics $(\bowtie) \cdot$ B. Kollár $\cdot$ Z. Kertész $\cdot$ M. Egyed

Department of Internal Medicine, Division of Hematology,

Kaposi Mór Teaching Hospital,

Tallián Gy. str. 20-32,

7400 Kaposvár, Hungary

e-mail: rajnicsp@hotmail.com

\section{J. Demeter}

First Department of Internal Medicine, Division of Hematology,

Semmelweis University of Budapest,

Budapest, Hungary

J. Csomor

Department of Pathology, St. László Hospital,

Budapest, Hungary

L. Krenács

Laboratory of Tumor Pathology and Molecular Diagnostics, Institute of Biotechnology,

Bay Zoltan Foundation for Applied Research,

Szeged, Hungary

L. Pajor

Department of Pathology, University of Pécs,

Pécs, Hungary all cases. The two young patients are disease-free nowadays; the older patient with poor prognostic histologicaltype lymphoma relapsed in a short time and died after second relapse. A multicenter analysis is necessary to evaluate the long-term results of chemoimmunotherapy in these rare extranodal lymphoma entities.

Keywords Primary extranodal lymphoma · Diffuse large B-cell lymphoma · Uterine lymphoma · Prostate lymphoma . Rituximab-based therapy

\section{Introduction}

The incidence of non-Hodgkin's lymphoma (NHL) has risen steadily since the 1930s, according to the Connecticut tumor registry. The average annual age-standardized rate of NHL in men rose from 3.5 per 100,000 in 1935-1939 to 20 per 100,000 in 1990-1994 [1]. The majority of this increase may reflect improvements in detection and pathological diagnosis rather than incidence. Diffuse large B-cell lymphoma (DLBCL) is the most common type of NHL in western countries, representing approximately one third of the total. Thirty percent of the NHLs arise in tissues different from the lymph node; therefore, they are usually termed extranodal lymphomas [2-5]. Approximately one quarter of DLBCLs have a primary extranodal origin. Most frequently, they occur in the gastrointestinal tract, especially in the gastric mucosa. They also occur in the lungs, in the skin, as testicular lymphomas, or in the central nervous system.

Primary NHL of the genital tract is extremely rare. Only $0.5 \%$ of the extranodal lymphomas in women are likely to originate in the female genital tract $[6,7]$. The prostate is a rare extranodal site of malignant lymphoma. Patel et al. reported a frequency of $<10 \%$ of urinary tract involvement 
by NHL, with $<1 \%$ involving the prostate [8]. Etiology and pathogenesis of primary genital tract NHLs are unknown, although there might be a possible association between chronic inflammation and lymphomas [9]. Computed tomography (CT) and magnetic resonance imaging (MRI) are useful in the diagnosis and staging, but their specificity is low $[10,11]$. Because of the low incidence, there is no widely accepted consensus on its management. According to the literature, the cornerstone of the therapy consists of irradiation alone or irradiation with either surgery or chemotherapy [12-18].

In this paper, we present three cases with Ann Arbor stage IE DLBCL of the genital tract. The differential diagnosis and the results of the treatment are also discussed.

\section{Materials and methods}

\section{Patient's characteristics}

The main characteristics of the patients are listed in Table 1. All patients had low or low-intermediate risk according to the international prognostic index (IPI). Staging procedures included cervical, thoracic, abdominal, and pelvic CT scans and bone marrow biopsy in all cases. All patients were treated with rituximab-CHOP (rituximab dose was $375 \mathrm{mg} / \mathrm{m}^{2}$, cyclophosphamide dose was $750 \mathrm{mg} / \mathrm{m}^{2}$, doxorubicin dose was $50 \mathrm{mg} / \mathrm{m}^{2}$, and vincristine dose was $1.4 \mathrm{mg} / \mathrm{m}^{2}$ in the first day of cycle and prednisone $100 \mathrm{mg}$ orally in first to fifth days of each cycle) chemoimmunotherapy in 21 days of cycles. The regimen administered depended on the risk according to the age-adjusted IPI. Post-therapy restaging consisted of repetition of tests and/or biopsies that previously had abnormal results. Complete response (CR) was defined as the total disappearance of tumor masses and diseaserelated symptoms and normalization of abnormal test results for at least 2 months. Partial response was defined as a decrease in tumor mass or organ infiltration of at least $50 \%$, along with the disappearance of disease-related symptoms. Patients not included in these categories were considered non-responders. The diagnosis of DLBCL was based on the criteria established in the World Health Organization classification [19].

Case 1

A 45-year-old woman with a 3-month history of postmenopausal vaginal bloody discharge was referred to our department of obstetrics and gynecology. Histological samples of fractionated curettage did not show endometrial malignancy. Blood test revealed elevated creatinine and blood urea nitrogen values; the abdominal and pelvic CT showed enlarged, infiltrated uterus and the tumor invaded to the parametrium, which causes bilateral ureterohydronephrosis. Percutaneous transrenal urinary catheter was fixed, and a punch biopsy from the uterine mass and parametrium was performed.

Histologically, the infiltrate was heterogenous; the main elements were blastic cells with roundish nucleus and several nucleoli resembling centroblasts. The immunohistochemical analysis showed an evidence of massive positivity to CD45 and B-cell markers including CD20. These findings established the diagnosis of a DLBCL. Additional immunohistochemical analysis was done later; the tumor cells were CD10, CD30, CD5, and MUM-1 negative and bcl-6 positive; this phenotype suggests a germinal center (GC) derivation for the tumor cells. Sixty percent of the tumor cells showed intensive positivity to Ki-67 nuclear proliferative antigen.

Bone marrow biopsy was normal; blood count revealed mild microcytic anemia. The staging computerized tomography of the thorax, abdomen, and pelvis did not show lymphadenomegaly.

Six cycles of chemoimmunotherapy (R-CHOP) were administered. Complete remission was achieved after six cycles according to the restaging $\mathrm{CT}$ and MR. The patient was disease-free during the next 48 months.

Case 2

A 26-year-old woman visited the gynecological unit of our hospital complaining to an atypical contact vaginal bleed-

Table 1 Patients characteristics

\begin{tabular}{|c|c|c|c|c|c|c|c|c|c|c|}
\hline Patients & $\begin{array}{l}\text { Age } \\
\text { (years) }\end{array}$ & Localization & $\begin{array}{l}\text { Ann Arbor } \\
\text { stage }\end{array}$ & IPI & $\begin{array}{l}\text { DLBCL } \\
\text { subtype }\end{array}$ & $\begin{array}{l}\text { First-line } \\
\text { treatment }\end{array}$ & Response & $\begin{array}{l}\text { Time to } \\
\text { relapse } \\
\text { (months) }\end{array}$ & $\begin{array}{l}\text { Treatment } \\
\text { of relapse }\end{array}$ & $\begin{array}{l}\text { Survival } \\
\text { (months) }\end{array}$ \\
\hline 1 & 45 & Uterus & $\mathrm{I} / \mathrm{E}$ & 2 & GC-type & $6 \times \mathrm{R}-\mathrm{CHOP}$ & $\mathrm{CR}$ & No & No & 48 (live) \\
\hline 2 & 26 & Uterus & $\mathrm{I} / \mathrm{E}$ & 0 & GC-type & $6 \times \mathrm{R}-\mathrm{CHOP}$ & $\mathrm{CR}$ & No & No & 60 (live) \\
\hline 3 & 73 & Prostate & $\mathrm{I} / \mathrm{E}$ & 2 & Intravascular & $8 \times \mathrm{R}-\mathrm{CHOP}$ & $\mathrm{CR}$ & 12 & $\begin{array}{l}6 \text { cycles } \\
\text { of IEV }\end{array}$ & 30 (died) \\
\hline
\end{tabular}

IPI international prognostic index 
ing during the last 1 year. Her Papanicolaou smear was P II. The performed fractionated curettage revealed smooth internal surface of the uterus with a measured cavity length of $7 \mathrm{~cm}$. The histological assessment of the obtained tissue sample showed cervical and endometrial gland parts surrounded by proliferating diffuse cellular infiltrate. The main elements were blastic cells with roundish nucleus and several nucleoli. There were reactive cells as well as small lymphocytes, plasma cells, and eosinophils. During the immunohistochemical analysis, these cellular elements were negative to myeloid markers and cytokeratin but showed massive positivity to CD45 and B-cell markers including CD20. These findings established the diagnosis of a DLBCL. The tumor cells were CD10 and MUM-1 negative and bcl-6 positive: the tumor was a GC-type DLBCL. There was no palpable spleno-, hepato-, or lymphadenomegaly. The transvaginal ultrasonography showed a normal-sized uterus $(84 \times 52 \mathrm{~mm})$ with normal myometrial structure and a 3-mm thick endometrial layer. The staging CT scan was completed by pelvic MRI. The MR examination did not indicate any myometrial, nodal, or other organ involvement (Ann Arbor stage IE, IPI: 0). Six cycles of rituximab combined standard CHOP chemotherapy (RCHOP) were administered without any complication. After completion of chemoimmunotherapy, transvaginal ultrasonography showed again a normal-sized uterus $(79 \times 51 \mathrm{~mm})$ with a $5.7-\mathrm{mm}$ thick endometrium. As a control, a new fractionated curettage was done. The repeated histopathological review of the obtained endometrial sample showed normal secretory endometrial mucosa. There was not any confirming sign of the existence of the previously found DLBCL, meaning, the patient achieved complete remission. After 24 months follow-up, the patient is completely free from the disease.

\section{Case 3}

A 73-year-old male patient presented a 1-month history of weak urinary stream and dysuria with mild hematuria. Digital rectal examination showed a voluminous prostate with fibroelastic consistency. Blood test revealed normal prostate-specific antigen (PSA; $1.18 \mathrm{ug} / \mathrm{L})$. Ultrasonography of the urinary tract showed a $7 \times 8$-cm enlarged prostate with moderate bilateral uretero-hydronephrosis. Urinary catheter was fixed because of $600-\mathrm{ml}$ urinary bladder retention. Later, open transvesical prostatectomy was performed because of total urinary retention. Blood vessels conglomeratum filled out with large discohesive cells was observed in the prostatic tissue microscopically. The cells had thin basophilic cytoplasm, pleomorphic nuclei, and prominent nucleoli. Between these malignant cells, many red blood cells and fibrin thrombi were situated. Immunohistochemically, malignant cells expressed CD20, leukocyte common antigen (LCA), and CD79- $\alpha$ and were negative for CD10, MUM-1, and bcl-2. Nearly $100 \%$ of the tumor cells showed intensive positivity to Ki-67 nuclear proliferation antigen. These histological results confirmed an intravascular DLBCL of the prostate. Bone scintigraphy was negative for secondary lesions. Bone marrow biopsy, complete blood count, and staging CT were normal. Using the Bostwick and Mann [20] criteria, the diagnosis of primary extranodal lymphoma of the prostate was confirmed (Ann Arbor stage IE). He was administered eight cycles of chemoimmunotherapy (R-CHOP). Complete remission was achieved after eight cycles according to the restaging procedures. The patient was disease-free during the next 12 months. After 1 year, B-symptoms and left inguinal lymphadenomegaly developed; the histology showed relapsed DLBCL. He was administered six cycles of chemotherapy IEV (ifosfamide, epirubicine, and etoposide). Complete remission had been achieved again. After 3 months, the B-symptoms developed again, and abdominal lymphadenomegaly appeared; the DLBCL relapsed. Opposite to the next salvage chemotherapy, the patient died in septic condition after 2 months later.

\section{Discussion}

During the last two decades, the incidence of lymphomas has increased, and the incidence of extranodal lymphomas increased more rapidly than nodal $[4,5,21]$. Lymphomas presenting in extranodal organs with no or only minor lymph node involvement are considered primary extranodal. Primary NHL of the genital tract is extremely rare. The most common histological subtype is DLBCL [22]. Other rare B-cell lymphomas in the uterine cervix are marginal zone B-cell lymphoma and mucosa-associated lymphoid tissue lymphoma [22, 23].

DLBCLs have been separated by means of microarray in two different groups according to the GC or post-GC genetic signature, with different clinicobiologic features and outcome [24-28]. There is still no information available about the gene expression profile according to the primary site of the lymphoma [29]. Morphologically, DLBCL show the whole spectrum of peripheral B-blasts: centroblasts, immunoblasts, or plasmoblasts. Thus, there is no actual difference in their cytomorphological presentation compared to their nodal — and frequently systemic - counterparts [30].

Terol et al. examined the soluble ICAM-1 level in patients with extranodal and nodal DLBCLs. There was not any difference in s-ICAM-1 levels between patients with extranodal involvement compared with those with nodal disease or between those with two or more extranodal sites versus the others. No relationship was found between s-ICAM-1 levels and the IPI score. There was a significant 
negative correlation between the levels of s-ICAM-1 and achievement of a CR [31]. Prognosis of extranodal lymphomas is usually poorer than nodal lymphomas because of inaccurate or delayed diagnosis [32]. Ann Arbor stage, size, and extent of disease, age, number of extranodal sites, performance status, serum lactate dehydrogenase values, and grade of lymphoma are significant prognostic features.

\section{Uterine lymphoma}

Abnormal uterine bleeding is the most common presenting symptom. Other frequent complaints are postcoital bleeding, dyspareunia, pelvic pain, and postmenopausal bleeding $[11,33,34]$. Differential diagnosis of primary uterine lymphomas includes benign inflammatory and malignant disease such as cervical or corpus carcinomas, sarcomas, and lymphoma-like lesions [22, 35, 36]. For a definitive diagnosis, a deep biopsy or fractionated curettage with histopathological evaluation and immunophenotyping are required $[35,36]$. Because such located lymphomas are subepithelial and unless there is ulceration and exfoliation, Papanicolaou smear plays a very insignificant role in the diagnosis of cervical lymphoma.

Because of the rarity, there is not an established treatment protocol for primary NHLs of the genital tract. Radiotherapy, chemotherapy, and surgery, either alone or in combination, are the mainstay of the treatment [33, 34, 37-39]. On the basis of recent studies [40, 41], the standard and effective DLBCL therapy, regardless of age, localization, stage, or IPI, is the anti-CD20 immunochemotherapy (R-CHOP). Because of the very few cases reported and in the light of results, usefulness of described treatment options including total abdominal hysterectomy, salpingo-oophorectomy, pelvic node dissection, radiotherapy, and/or chemotherapy are controversial.

Rituximab was the first monoclonal antibody, which has been registered for the treatment of B-cell lymphomas. The use of rituximab has been rapidly incorporated in clinical practice because of its significant clinical activity and few adverse effects [42].

Rituximab is also used for treatment of primary NHL of the cervix [43]. In the literature, there are six cases with large B-cell histology. They were treated with chemotherapy plus rituximab as a first-line regimen with promising results $[38,39,44]$.

\section{Prostate lymphoma}

Primary lymphomas of the prostate account for $0.09 \%$ of prostate neoplasms and $0.1 \%$ of all NHLs [45]. Bostwick and Mann [20] determined which cases are acceptable as primary lymphoma of the prostate: (1) presenting symp- toms attributable to prostatic enlargement; (2) involvement of the prostate predominantly, with or without involvement of adjacent tissue; and (3) absence of involvement of the liver, spleen, or lymph nodes within 1 month of diagnosis of prostatic involvement. All histological types of lymphoma have been described, with DLBCL being most common [46]. The clinical presentation of malignant lymphoma of the prostate is difficult to distinguish from other prostatic diseases causing lower urinary tract obstructive symptoms. Urgency and micturition were the most common presenting symptoms, with occasional hematuria and acute retention. The serum PSA is always normal. A diagnosis of suspicion can be made by urine cytology and histopathological analysis with immunohistochemical techniques, and molecular studies are mandatory to reach final diagnosis [46]. The differential diagnosis of prostatic lymphoma from the clinical standpoint is difficult, particularly when it is primary to the prostate. Differential diagnosis includes prostatitis, small cell carcinoma, lymphoepithelioma-like carcinoma, and Hodgkin lymphoma (HL). The distinction between lymphoma and other malignant tumors can be readily accomplished immunohistochemically, and inflammatory conditions can be ruled out according to morphological criteria. Negativity for CD15 and LMP-1 helps to exclude HL [47]. The presence of malignant acini or atypical lymphocytes usually is definitive, although highgrade prostatic carcinoma can present as infiltrating single cells with no acinar formation, mimicking lymphoma. Reactivity for the immunohistochemical stain LCA and lack of reactivity for prostate-specific antigen and prostatic acid phosphatase can favor the diagnosis of lymphoma in difficult cases. Lack of reactivity for cytokeratins can exclude extraprostatic carcinomas, such as bladder carcinoma, that may infiltrate into or metastasize to the prostate. Several therapeutic modalities have been reported, including prostatectomy, radiotherapy, chemotherapy, and even cystoprostatectomy [20,48]. Among the 23 cases of primary lymphoma of the prostate reported in the Japanese literature, three out of five cases treated with radiotherapy or radical prostatectomy resulted in death or progression of disease. On the other hand, 11 out of 16 cases (69\%) that received chemotherapy alone or associated with other treatments had a full response [49]. Chemotherapy constitutes the primary therapeutic approach. R-CHOP became the new treatment standard of DLBCL. Lymphoma-specific survival did not differ between primary and secondary involvement, in contrast to bladder and ovarian [50] lymphoma, in which patients with secondary lymphoma fared worse. The improvement in the survival of patients diagnosed after 1980 cannot be explained definitely but may be attributable to earlier detection and therapy that is more effective. Prognosis apparently was related to the primary generalized lymphoma rather than to the extent of 
prostatic infiltration [51]. The prognosis remains poor regardless of patient's age, histological type, treatment, or clinical stage of disease at presentation.

Our three cases demonstrated that the R-CHOP chemoimmunotherapy was a good and tolerable treatment option in all cases. The two young patients are disease-free nowadays; the older patient with poor prognostic histological-type lymphoma relapsed in a short time and died after second relapse. A multicenter analysis is necessary to evaluate the long-term results of chemoimmunotherapy in these rare extranodal lymphoma entities.

\section{References}

1. Polednak AP (1997) Trends in cancer incidence in Connecticut. Conn Med 61:211-218

2. Harris NL (2001) Mature B-cell neoplasms. In: Jaffe EJ, Harris $\mathrm{NL}$, Stein $\mathrm{H}$ et al (eds) WHO classification of tumours: pathology and genetics of tumours of haematopoietic and lymphoid tissues. IARC Press, Lyon, France, pp 121-126

3. Zucca E, Cavalli F (2000) Extranodal lymphomas. Ann Oncol 11 (Suppl 3):S219-S222

4. Zucca E, Roggero E, Bertoni F (1997) Primary extranodal nonHodgkin's lymphomas, part 1: gastrointestinal, cutaneous and genitourinary lymphomas. Ann Oncol 8:727-737. doi:10.1023/ A: 1008282818705

5. Zucca E, Roggero E, Bertoni F (1999) Primary extranodal nonHodgkin's lymphomas, part 2: head and neck, central nervous system and other less common sites. Ann Oncol 10:1023-1033. doi:10.1023/A:1008313229892

6. Freeman C, Berg JW, Cutler SJ (1972) Occurance and prognosis of extranodal lymphomas. Cancer 29(1):252-260. doi:10.1002/ 1097-0142(197201)29:1<252::AID-CNCR2820290138>>3.0. CO;2-\#

7. Charlton I, Karnei RF, King FM, Norris HJ (1974) Primary malignant reticuloendothelial disease involving the vagina, cervix and corpus uteri. Obstet Gynecol 44:735-748

8. Patel DR, Gomez GA, Henderson ES, Gamarra M (1988) Primary prostatic involvement in non-Hodgkin lymphoma. Urology 32:96-98. doi:10.1016/0090-4295(88)90305-6

9. Aozasa K, Saeki K, Ohsawa M, Horiuchi K, Mishima K, Tsujimoto M (1993) Malignant lymphoma of the uterus. Report of seven cases with immunohistochemical study. Cancer 72(6):19591964. doi:10.1002/1097-0142(19930915)72:6<1959::AIDCNCR2820720628>3.0.CO;2-P

10. Bode MK, Tikkakoski T, Johansson J, Johansson K, Kariniemi J, Apaja-Sarkkinen M, Tuominen H (2002) Lymphoma of the cervix. Acta Radiol 43(4):431-432. doi:10.1034/j.16000455.2002.430417.x

11. Thyagarajan MS, Dobson MJ, Biswas A (2004) Appearance of uterine cervical lymphoma on MRI: a case report and review of the literature. Br J Radiol 77:512-515. doi:10.1259/bjr/58044417

12. Awwad JT, Khalil AM, Shamseddine AI, Muffarij AA (1994) Primary malignant lymphoma of the uterine cervix: is radiotherapy the best therapeutic choice for stage IE? Gynecol Oncol 52:91-93. doi:10.1006/gyno.1994.1017

13. Stroh EL, Besa PC, Cox JD, Fuller LM, Cabanillas FF (1995) Treatment of patients with lymphomas of the uterus or cervix, with combination chemotherapy and radiation therapy. Cancer 75:2392 2399. doi:10.1002/1097-0142(19950501)75:9<2392::AIDCNCR2820750932>3.0.CO;2-Y
14. Amichetti M, Chiappe E, Mussari S, Busana L, Caffo O, Botto F, Galligioni E, Tomio L (1999) Primary non-Hodgkin's lymphoma of the female genital tract. Oncol Rep 6:651-654

15. Muntz HG, Ferry JA, Flynn D, Fuller AF, Tarraza HM (1991) Stage IE primary malignant lymphomas of the uterine cervix. Cancer 68:2023-2032. doi:10.1002/1097-0142(19911101) 68:9<2023::AID-CNCR2820680930>3.0.CO;2-V

16. Chandy L, Kumar L, Dawar R (1998) Non-Hodgkin's lymphoma presenting as a primary lesion in uterine cervix: case report. J Obstet Gynaecol Res 24:183-187

17. Maryniak RK, Nasierowska-Guttmejer A (1993) Primary malignant lymphoma of the uterine cervix. A clinicopathological evaluation of 3 cases. Eur J Gynaecol Oncol 13:402-405

18. Makarewicz R, Kuzminska A (1995) Non-Hodgkin's lymphoma of the uterine cervix: report of three patients. Clin Oncol 7:198 199. doi:10.1016/S0936-6555(05)80517-5

19. Gatter KC, Warnke RA (2001) Diffuse large B-cell lymphoma. In: Jaffe ES, Harris NL, Stein H (eds) WHO classification of tumors: pathology and genetics of hematopoietic and lymphoid tissues. IARC Press, Lyon, France, pp 171-174

20. Bostwick DG, Mann RB (1985) Malignant lymphomas involving the prostate. A study of 13 cases. Cancer 56:2932-2938. doi:10.1002/1097-0142(19851215)56:12<2932::AIDCNCR2820561234>3.0.CO;2-H

21. Groves FD, Linet MS, Travis LB (1995) Cancer surveillance series: non-Hodgkin's lymphoma incidence by histologic subtype in the United States from 1978 through 1995. J Natl Cancer Inst 92:1240-1251. doi:10.1093/jnci/92.15.1240

22. Vang R, Medeiros LJ, Ha CS, Deavers M (2000) Non-Hodgkin's lymphomas involving the uterus: a clinicopathologic analysis of 26 cases. Mod Pathol 13:19-28. doi:10.1038/modpathol.3880005

23. Vang R, Medeiros LJ, Fuller GN, Sarris AH, Deavers M (2001) Non-Hodgkin's lymphoma involving the gynecologic tract: a review of 88 cases. Adv Anat Pathol 8:200-217. doi:10.1097/ 00125480-200107000-00002

24. Alizadeh AA, Elsen MB, Davis RE (2000) Distinct types of diffuse large B-cell lymphoma identified by gene expression profiling. Nature 403:503-511. doi:10.1038/35000501

25. Shipp MA, Ross KN, Tamayo P (2002) Diffuse large B-cell lymphoma outcome prediction by gene-expression profiling and supervised machine learning. Nat Med 8:68-74. doi:10.1038/ nm0102-68

26. Rosenwald A, Wright G, Chan WC (2002) The use of molecular profiling to predict survival after chemotherapy for diffuse largeB-cell lymphoma. N Engl J Med 346:1937-1947. doi:10.1056/ NEJMoa012914

27. Lossos IS, Czerwinski DK, Alizadeh AA (2004) Prediction of survival in diffuse large-B-cell lymphoma based on the expression of six genes. N Engl J Med 350:1828-1837. doi:10.1056/ NEJMoa032520

28. Sáez AI, Sáez AJ, Artiga MJ (2004) Building an outcome predictor model for diffuse large B-cell lymphoma. Am J Pathol 164:613-622

29. López-Guillermo A, Colomo L, Jiménez M, Bosch F, Villamor N, Arenillas L, Muntañola $\mathrm{A}$, Montoto $\mathrm{S}$, Giné $\mathrm{E}$, Colomer $\mathrm{D}$, Beà $\mathrm{S}$, Campo E, Montserrat E (2005) Diffuse large B-cell lymphoma: clinical and biological characterization and outcome according to the nodal or extranodal primary origin. J Clin Oncol 23(12):27972804. doi: $10.1200 / \mathrm{JCO} .2005 .07 .155$

30. Ott G, Rosenwald A (2007) Extranodal diffuse large B-cell lymphoma - an organotypic disease? Pathologe 28(1):29-35

31. Terol MJ, Tormo M, Martinez-Climent JA, Marugan I, Benet I, Ferrandez A, Teruel A, Ferrer R, García-Conde J (2003) Soluble intercellular adhesion molecule-1 (s-ICAM-1/s-CD54) in diffuse large B-cell lymphoma: association with clinical characteristics and outcome. Ann Oncol 14(3):467-474 
32. Trenhaile TR, Killackey MA (2001) Primary pelvic nonHodgkin's lymphoma. Obstet Gynecol 97(5):717-720. doi:10.1016/S0029-7844(00)01225-4

33. Lee KM, Seah ES, Sethi VK (1998) Primary non-Hodgkin's lymphoma of the uterine cervix: case report of long-term survival of two patients treated with surgery and radiotherapy. Australas Radiol 42:126-127. doi:10.1111/j.1440-1673.1998.tb00587.x

34. Van Renterghem N, De Paepe P, Van den Broecke R, Bourgain C, Serreyn R (2005) Primary lymphoma of the cervix uteri: a diagnostic challenge. Report of two cases and review of the literature. Eur J Gynaecol Oncol 26(1):36-38

35. Kuo HC, Chou CY, Chang CH, Liu MT, Tzeng CC, Huang KE (1994) Primary malignant lymphoma of the uterine cervix shows favorable response to neoadjuvant chemotherapy. Gynecol Oncol 52(3):408-410. doi:10.1006/gyno.1994.1070

36. Szantho A, Balega JJ, Csapo Z, Sreter LL, Matolcsy A, Papp Z (2003) Primary non-Hodgkin's lymphoma of the uterine cervix successfully treated by neoadjuvant chemotherapy: case report. Gynecol Oncol 89(1):171-174. doi:10.1016/S0090-8258(03) 00057-X

37. Hariprasad R, Kumar L, Bhatla N, Kukreja M, Papaiah S (2006) Primary uterine lymphoma: report of 2 cases and review of literature. Am J Obstet Gynecol 195:308-313. doi:10.1016/j. ajog.2006.04.002

38. Frey NV, Svoboda J, Andreadis C, Tsai DE, Schuster SJ, Elstrom R, Rubin SC, Nasta SD (2006) Primary lymphomas of the cervix and uterus: the University of Pennsylvania's experience and a review of the literature. Leuk Lymphoma 47(9):1894-1901. doi:10.1080/10428190600687653

39. Cohn DE, Resnick KE, Eaton LA, deHart J, Zanagnolo V (2007) Non-Hodgkin's lymphoma mimicking gynecological malignancies of the vagina and cervix: a report of four cases. Int J Gynecol Cancer 17(1):274-279. doi:10.1111/j.1525-1438.2006.00747.x

40. Coiffier B, Lepage E, Briere J, Herbrecht R, Tilly H, Bouabdallah R, Morel P, van den Neste E, Salles G, Gaulard P, Reyes F, Lederlin P, Gisselbrecht C (2002) CHOP chemotherapy plus rituximab compared with $\mathrm{CHOP}$ alone in elderly patients with diffuse large-B-cell lymphoma. N Engl J Med 346(4):235-242. doi:10.1056/NEJMoa011795

41. Pfreundschuh MG, Trümper L, Ma D, Österborg A, Pettengell R, Trneny M, Shepherd L, Waleswski J, Zinzani PL, Loeffler M
(2004) Randomised intergroup trial of first line treatment for patients $<60$ years with diffuse large B-cell non-Hodgkin's lymphoma (DLBCL) with a CHOP-like regimen with or without the anti-CD20 antibody rituximab - early stopping after the first interim analysis. J Clin Oncol, ASCO Annual Meeting Proceedings 22(14S):6500

42. Boye J, Elter T, Engert A (2003) An overview of the current clinical use of anti-CD20 monoclonal antibody rituximab. Ann Oncol 14:520-535. doi:10.1093/annonc/mdg175

43. Pham DC, Guthrie TH, Ndubisi B (2003) HIV-associated primary cervical non-Hodgkin's lymphoma and two other cases of primary pelvic non-Hodgkin's lymphoma. Gynecol Oncol 90(1):204-206. doi:10.1016/S0090-8258(03)00223-3

44. Kendrick JE 4th, Straughn JM Jr (2005) Two cases of nonHodgkin's lymphoma presenting as primary gynecologic malignancies. Gynecol Oncol 98(3):490-492. doi:10.1016/j. ygyno.2005.04.033

45. Ferry JA, Young RH (1997) Malignant lymphoma of the genitourinary tract. Curr Diagn Pathol 4:145-169. doi:10.1016/ S0968-6053(05)80004-3

46. Bostwick DG, Iczkowski KA, Amin MB, Discigil G, Osborne B (1998) Malignant lymphoma involving the prostate: report of 62 cases. Cancer 83:732-738. doi:10.1002/(SICI)1097-0142 (19980815)83:4<732::AID-CNCR15>3.0.CO;2-T

47. Alvarez CA, Rodriguez BI, Perez LA (2006) Primary diffuse large B-cell lymphoma of the prostate in a young patient. Int Braz $\mathrm{J}$ Urol 32(1):64-65

48. Sarris A, Dimopoulos M, Pugh W, Cabanillas F (1995) Primary lymphoma of the prostate: good outcome with doxorubicin-based combination chemotherapy. J Urol 153:1852-1854. doi:10.1016/ S0022-5347(01)67330-0

49. Fukutani K, Koyama Y, Fujimori M, Ishida T (2003) Primary malignant lymphoma of the prostate: report of a case achieving complete response to combination chemotherapy and review of 22 Japanese cases. Nippon Hinyokika Gakkai Zasshi 94:621-625

50. Monterroso V, Jaffe ES, Merino MJ, Medieros LJ (1993) Malignant lymphomas involving the ovary: a clinicopathologic analysis of 39 cases. Am J Surg Pathol 17:154-170. doi:10.1097/ 00000478-199302000-00007

51. Sridhar KN, Woodhouse CRJ (1983) Prostatic infiltration in leukaemia and lymphoma. Eur Urol 9:153-156 